\title{
Racial disparities in hematopoietic stem cell transplant: a systematic review of the literature
}

\author{
Ian Landry \\ Internal Medicine, Icahn School of Medicine at Mt Sinai, Queens Hospital Center, Jamaica, Queens, NY, USA \\ Correspondence to: Ian Landry, MD, MPH. 82-68 164th St, Jamaica, NY 11432, USA. Email: landryi@nychhc.org; ilandr87@gmail.com.
}

\begin{abstract}
Background: Hematopoietic stem cell transplant (HSCT) is an expensive and complex treatment regimen that can be curative in many diseases of the bone marrow, including malignant and non-malignant conditions. The introduction of the Affordable Care Act increased access to potential candidates and removed or reduced many barriers previously identified in the literature, however, racial disparities continue to persist. As HSCT expands its utilization and indications, there is a continued need to understand the multifactorial barriers which lead to inequalities in transplant referral, utilization, and survival. The objective of this systematic review is to summarize these racial disparities, expand the current understanding of the literature, and determine whether the increases in insurance status from Medicaid expansion have played a role in HSCT utilization and survival rates by race.

Methods: We explored studies based on retrospective reviews, literature reviews, and focus groups with the key-terms of 'race', 'hematopoietic stem cell transplant', and 'disparities'. The included studies were extracted from Cochrane and Medline databases. After screening for relevancy to research aims and objectives, 10 articles were utilized for background information and discussion, while 30 articles were categorized into main groups of outcomes, chiefly, (I) access/referral to transplant and (II) survival.
\end{abstract}

Results: Eight of the eleven retrospective reviews found substantial variation in access to HSCT by ethnic minorities (Black, Hispanic, or Asian) when compared to their Caucasian counterparts. Thirteen of the fourteen publications found racial disparities in either overall survival, progression free survival, treatment related mortality, relapse, or combinations of these outcomes. The majority of the studies evaluated African American patients with six of eight studies showing significantly elevated mortality compared to Caucasian patients.

Discussion: Substantial variation exists in access to HSCT, particularly in black patients. Having less generous insurance coverage was previously hypothesized to reduce the likelihood of HSCT utilization. Studies performed after full implementation of the Affordable Care Act continue to show poorer survival among ethnic minorities, particularly black patients, despite this increased coverage. Perceived racial bias and health-related stigma, as well as physician decisions and delay in referral process are likely contributing factors.

Keywords: Race; disparities; hematopoietic stem cell transplant; ethnicity

Received: 05 September 2021; Accepted: 06 December 2021; Published: 14 December 2021.

doi: 10.21037/sci-2021-058

View this article at: https://dx.doi.org/10.21037/sci-2021-058

\section{Background}

Hematopoietic stem cell transplant (HSCT) is an expensive and complex treatment regimen that can be curative in many diseases of the bone marrow, including malignant and non-malignant conditions. The introduction of the
Affordable Care Act increased access to potential candidates and removed or reduced many barriers previously identified in the literature, however, racial disparities continue to persist. As HSCT expands its utilization and indications, there is a continued need to understand the multifactorial 
barriers which lead to inequalities in transplant referral, utilization, and survival. The objective of this systematic review is to summarize these racial disparities, expand the current understanding of the literature, and determine whether the increases in insurance status from Medicaid expansion have played a role in HSCT utilization and survival rates by race.

Bone marrow transplant, otherwise known as hematopoietic stem cell transplant (HSCT), is the process by which diseased bone marrow cells are eradicated via high doses of chemotherapy and/or radiation, then subsequently replaced by transplanted donor cells. Depending on the underlying pathology, transplants are characterized as either autologous, syngeneic, or allogeneic. In an autologous transplant, the donor and the recipient are the same. In syngeneic or allogeneic transplants, patients receive stem cells from their identical twin or tissue matched donor, respectively. Since its inception with the first successful transplant performed in identical twins in 1957, the United States has estimated over 9,400 cases of allogeneic transplants per year and over 14,200 cases of autologous transplants per year (1). Upon further stratification of allogeneic transplant recipients by donor type, recipients of unrelated donor transplants represent the largest group, surpassing those from related donors with over 4,500 cases per year (1). I present the following article in accordance with the PRISMA reporting checklist (available at https:// dx.doi.org/10.21037/sci-2021-058).

\section{Methods}

\section{Literature search}

We extracted publications covering a range of aspects related to HSCT and race or ethnicity. We assessed full-text articles in English language on these topics across databases including Medline, PubMed and Cochrane. As our goal was to assess trends in disparities in access to transplant and survival, we focused on extracting data from the initial publications on these topics to current literature. We formulated various combinations of keywords, including race, ethnicity, disparities, hematopoietic stem cell transplant, and bone marrow transplant in order to fetch articles of interest.

\section{Inclusion/exclusion parameters}

The included articles specifically focused on prospective or retrospective analyses, any relevant systematic reviews on disparities in hematopoietic stem cell transplant and focus groups which lend insight into patient or provider characteristics that influence the outcomes of interest.

\section{Selected studies}

The full-text publicly accessible studies were copied into our centralized database for their assessment and thematic analyses. The lead author screened each record and determined by abstract/title if the study was reasonably appropriate for further review. Once the initial screening process was complete, a secondary screening of the abstracts was done by the primary author to determine whether the studies assessed the outcomes of interest, chiefly, racial disparities in access or survival. As a method of quality assessment, a secondary independent reviewer screened the articles in the same fashion. Any disputes between the reviewers were discussed openly and deliberated to mutual satisfaction. Relative utilization rates, odds ratios, and relative risk were extracted and populated into appropriate external spreadsheets for further analysis. Two separate tables were created to summarize studies by the chief outcomes of interest. Tables included the data source analyzed, the population characteristics, the results of the study, and the conclusions reached by the authors. Odds ratios were then extracted from tables and separated by three primary ethnic groups (Hispanic, Asian, and African American). These odds ratios were placed into three separate forest plots to display the overall effect of the included studies. To assess for heterogeneity, the author specified the following hypothesis before conducting the analysis. We hypothesized that effect size may differ according to the methodological quality of the studies.

\section{Bias risk assessment}

Bias was assessed in this study by utilizing the National Institutes of Health (NIH) Study Quality Assessment Tool for Systematic Reviews and Meta-analyses (2). This review is based on a clearly stated question formulated through a PICO (population, intervention, comparator, outcome) format with clearly defined eligibility criteria. The literature search was comprehensive and conducted using multiple scientific literature databases. Assessment of the quality of the included studies was performed by the primary author and by an independent reviewer. Any disputes between the two reviewers were discussed and deliberated. All included 
Identification of studies via databases and registers

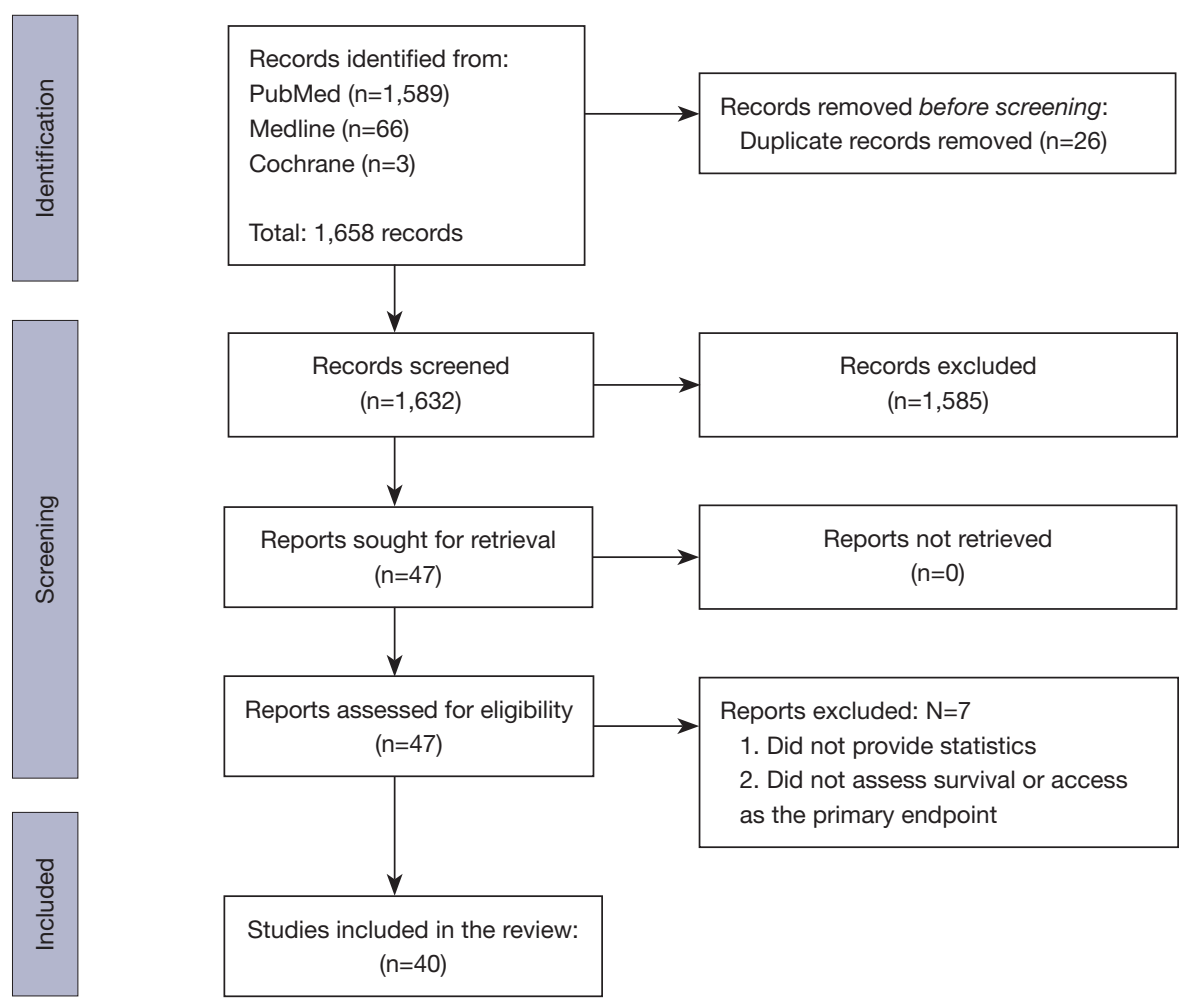

Figure 1 PRISMA flow diagram.

studies were listed in the review with descriptions of their key characteristics in table format. Outcomes of interest for survival presented in figures were assessed for heterogeneity by assessing the similarities between study populations, including racial and gender distributions in order to limit differences in their generalizability.

\section{Results}

Search results from Cochrane, PubMed, and Medline databases resulted in 14 and 1,606 respectively, with a total of 1,585 studies removed, leaving 47 studies included for secondary screening. Seven articles were excluded after screening of the full text. Finally, 40 articles were included for the main analysis (Figure 1). After screening for relevancy to research aims and objectives, 10 articles were utilized for background information and discussion, while 30 articles were categorized into main groups of outcomes, chiefly, (I) access/referral to transplant and (II) survival (Tables 1,2).

\section{Utilization of hematopoietic stem cell transplant}

We included seventeen publications which evaluated racial disparities and access to HSCT (Table 1). The publication distribution included eleven retrospective cohort studies, one literature review, three cross-sectional studies, and two focus group samplings. Eight of the eleven (73\%) retrospective reviews found substantial variation in access to HSCT by ethnic minorities (Black, Hispanic, or Asian) when compared to their Caucasian counterparts. One literature review found that disparities in race reporting existed when assigned by providers or healthcare centers, and that self-reported race is most accurate in identifying potential human leukocyte associated antigens (HLA)matches. One retrospective review found no statistically significant associations between payer status or ethnicity with HSCT use (3). One literature review concluded that race does not impact utilization as it is a sociopolitical construct, not a biological concept. 


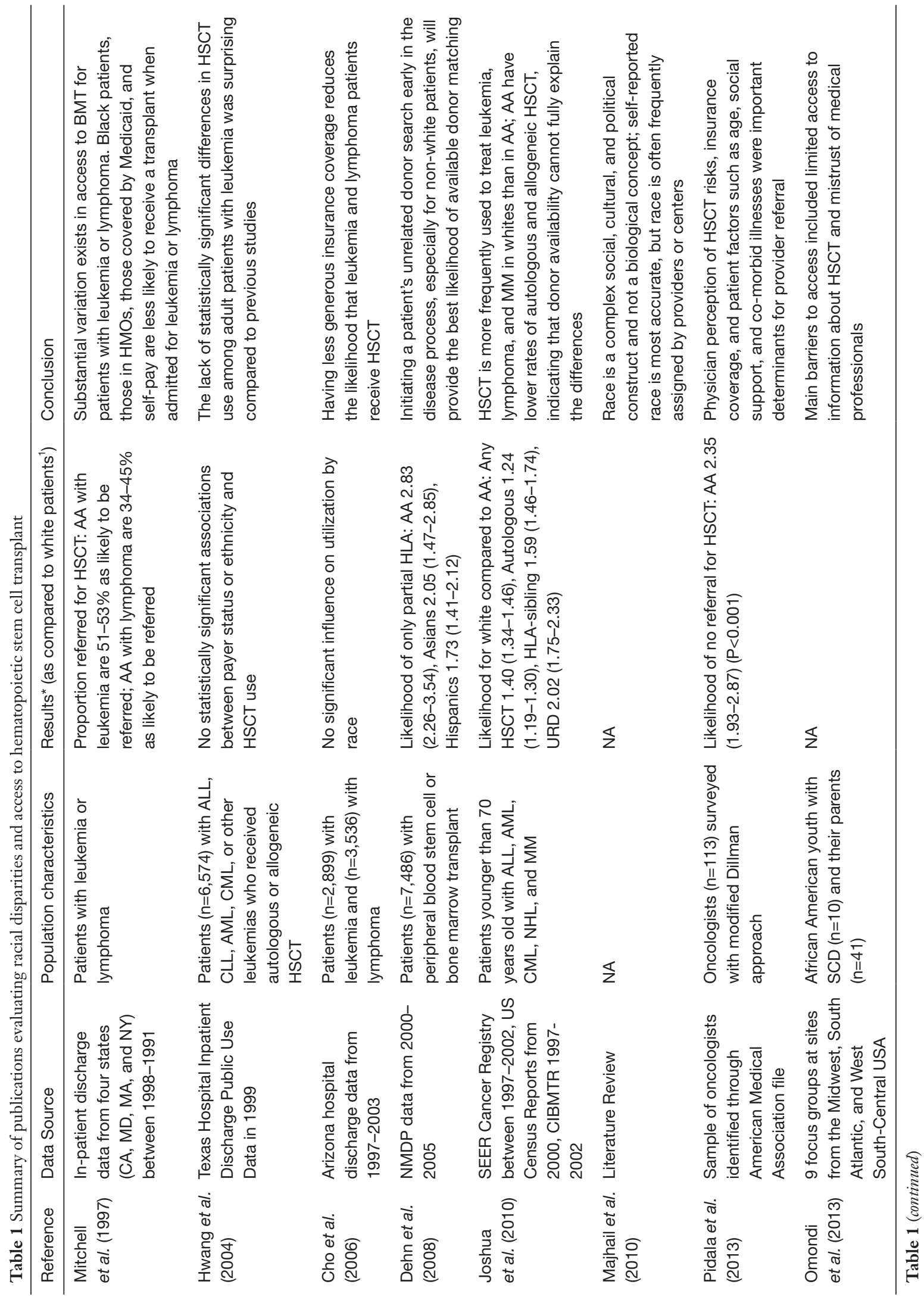




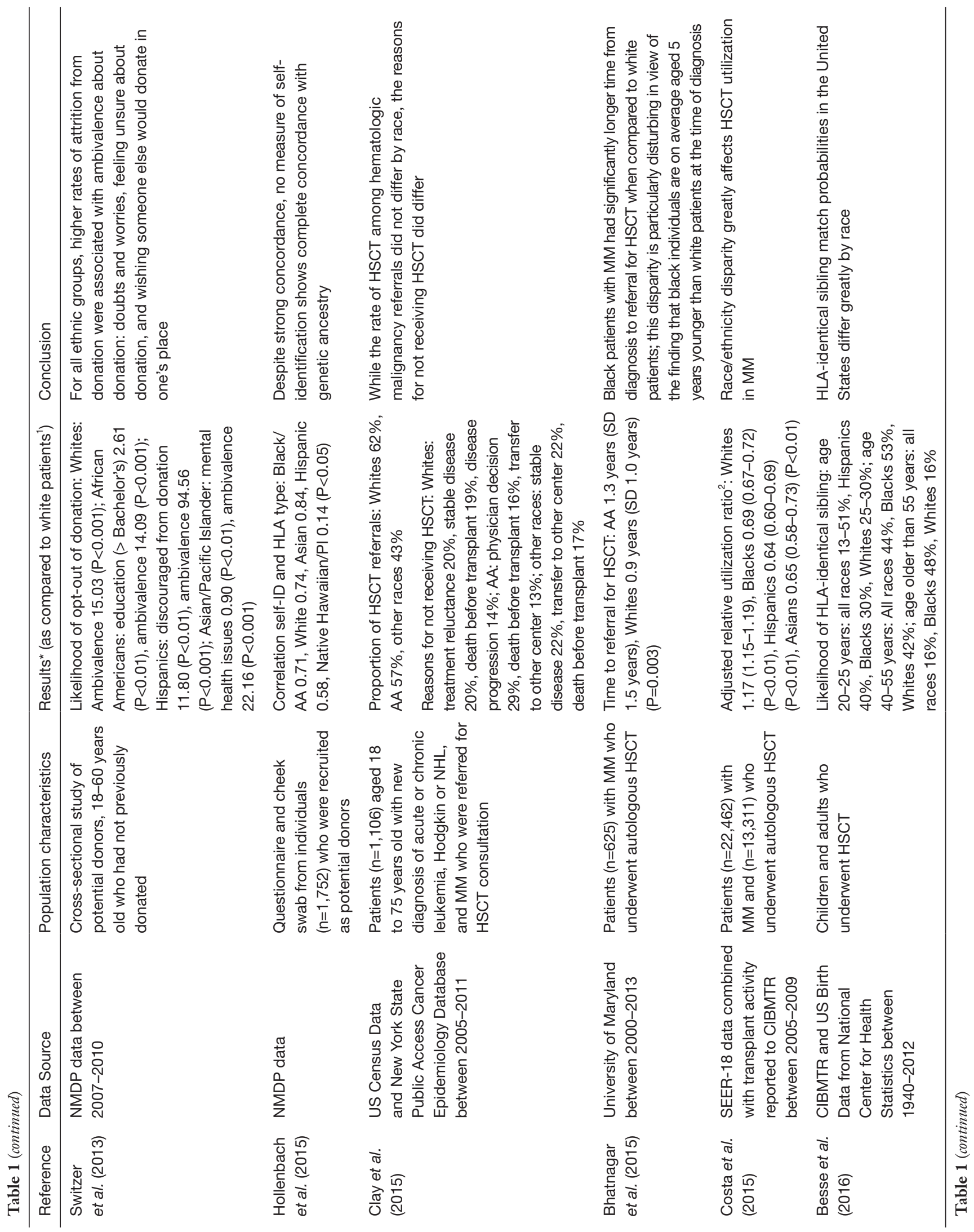




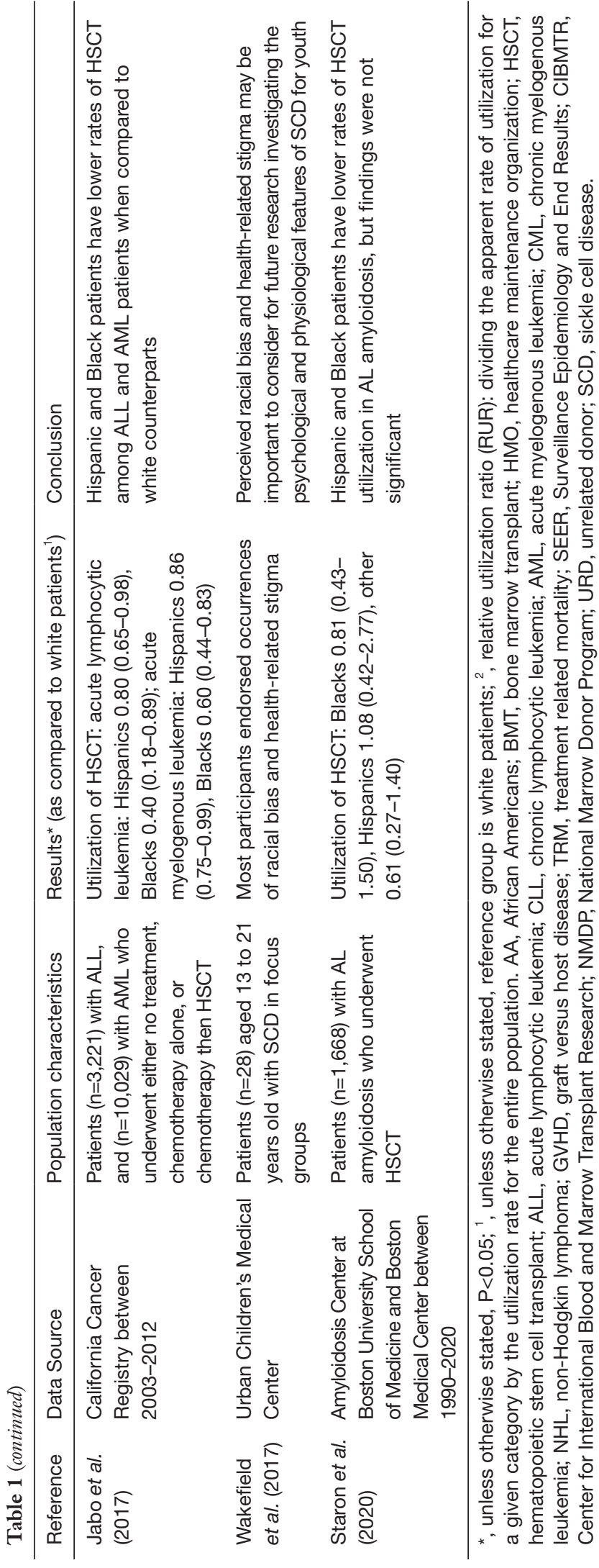

\section{Hispanic disparities in access to HSCT}

Seven of the seventeen publications addressed disparities in the Hispanic population. Five of the retrospective reviews found significant differences in access to HSCT. The likelihood of obtaining only a partial-HLA match in Hispanics was [OR 1.73 (1.41-2.12)] when compared to white patients in a study by Dehn et al. (4), whereas Besse et al. (5) showed that Hispanic patients in the 20-25 years old age group had similar odds of finding an HLA-match (40\%) when compared to white patients (25-30\%). Utilization of HSCT by Hispanic patients was evaluated by three retrospective reviews (6-8). Costa et al. (6) developed a relative utilization rate (RUR) which compared a particular group's utilization of autologous HSCT in multiple myeloma patients as a proportion of the utilization of the entire population. This study showed that Hispanics with multiple myeloma had a lower utilization rate [0.64 (0.60-0.69), $\mathrm{P}<0.01]$ when compared to the entire population. Similar disparities in acute lymphocytic leukemia (ALL), acute myelogenous leukemia (AML) and $\mathrm{AL}$ amyloidosis were also seen. Hispanics with ALL [0.80 (0.65-0.98)] and AML [0.86 (0.75-0.99] were significantly less likely to utilize HSCT in a California-based study (7), while Hispanic patients in Boston with AL amyloidosis (8) were [1.08 (0.42-2.77)] more likely to utilize HSCT, albeit non-significantly.

Two longitudinal studies evaluated access to HSCT by studying characteristics of potential stem cell donors or correlation of self-identified race with HLA-type. Switzer et al. (9) found that potential Hispanic stem cell donors were often more likely to be discouraged from donation $(11.80, \mathrm{P}<0.01)$ and had an overwhelming ambivalence (94.56, $\mathrm{P}<0.01)$ about donation, often feeling that they wished others would donate in their place. While this ambivalence was seen across all races, it was significantly higher in the Hispanic donors. Hollenbach et al. (10) utilized a questionnaire and cheek swab from potential donors to assess how self-identification of race/ethnicity correlates with actual HLA-type. This study showed that Hispanics had one of the lowest correlations between selfidentified race/ethnicity and HLA-type $(\mathrm{R}=0.58, \mathrm{P}<0.05)$ when compared to their African American $(\mathrm{R}=0.71)$ and Caucasian $(\mathrm{R}=0.74)$ counterparts.

\section{Asian disparities in access to HSCT}

Asian disparities were evaluated by four of the included studies. In two retrospective reviews, Asian patients 
Table 2 Summary of publications evaluating racial disparities and survival in hematopoietic stem cell transplant

\begin{tabular}{|c|c|c|c|c|}
\hline Reference & Data source & $\begin{array}{l}\text { Population } \\
\text { characteristics }\end{array}$ & Results $^{*}$ (as compared to white patients) ${ }^{1}$ & Conclusion \\
\hline $\begin{array}{l}\text { Serna } \\
\text { et al. } \\
(2003)\end{array}$ & $\begin{array}{l}\text { International Bone } \\
\text { Marrow Transplant } \\
\text { Registry between } \\
\text { 1985-1999 }\end{array}$ & $\begin{array}{l}\text { Patients }(\mathrm{n}=6,443 \text { ) } \\
\text { receiving HLA- } \\
\text { identical sibling } \\
\text { HSCT for acute or } \\
\text { chronic leukemia }\end{array}$ & $\begin{array}{l}\text { 1-year survival }(\mathrm{P}<0.01) \text { : Hispanics } 53 \% \text { vs. } 65 \% \\
\text { (whites) } \\
\text { 3-year survival }(\mathrm{P}<0.01) \text { : Hispanics } 38 \% \text { vs. } 53 \% \\
\text { (whites) } \\
\text { Overall survival: all races improved from } 56 \% \text { to } \\
63 \% \text { at } 1 \text {-year and } 43 \% \text { to } 51 \% \text { at } 3-y e a r s, \text { with } \\
\text { greater improvement among blacks } \\
\text { No significant differences in survival when } \\
\text { comparing blacks or Asians to whites }\end{array}$ & $\begin{array}{l}\text { Disparities remain in survival rates } \\
\text { between Whites and Hispanics } \\
\text { despite adjustment for clinical } \\
\text { factors }\end{array}$ \\
\hline $\begin{array}{l}\text { Baker } \\
\text { et al. } \\
(2005)\end{array}$ & $\begin{array}{l}\text { International Bone } \\
\text { Marrow Transplant } \\
\text { Registry between } \\
\text { 1990-2000 }\end{array}$ & $\begin{array}{l}\text { Patients }(n=3,028) \\
\text { with AML, ALL, or } \\
\text { CML who received } \\
\text { an HLA-identical } \\
\text { sibling HSCT }\end{array}$ & $\begin{array}{l}\text { Treatment failure: Hispanics } 1.30(1.08-1.54) \\
(\mathrm{P}<0.01) \\
\text { Overall mortality: Hispanics } 1.23(1.03-1.47) \\
(\mathrm{P}=0.02) \\
\text { No statistically significant differences in the } \\
\text { risk of acute or chronic GVHD, TRM, or relapse } \\
\text { between whites and any ethnic group }\end{array}$ & $\begin{array}{l}\text { Higher risks of treatment failure } \\
\text { and mortality in Hispanics may be } \\
\text { the net result of modest, but not } \\
\text { statistically significant increases } \\
\text { in relapse and TRM and cannot } \\
\text { be accounted for by transplant- } \\
\text { related complications }\end{array}$ \\
\hline $\begin{array}{l}\text { Mielcarek } \\
\text { et al. } \\
(2005)\end{array}$ & $\begin{array}{l}\text { Single institution } \\
\text { study between } \\
1992-2000\end{array}$ & $\begin{array}{l}\text { Patients ( } \mathrm{n}=3,587) \\
\text { who had } \\
\text { autologous or } \\
\text { allogeneic HSCT } \\
\text { at a single US } \\
\text { institution }\end{array}$ & $\begin{array}{l}\text { Autologous HSCT survival: no significant } \\
\text { association between race or ethnicity } \\
\text { Allogeneic HSCT survival: Blacks } 1.71(1.25- \\
2.34) \text {, Asians } 0.62(0.39-0.97)(P<0.05) \\
\text { Recurrent malignancy: Blacks } 1.61(0.95-2.73) \\
\text { Severe GVHD: } 61 \% \text { of blacks, } 36 \% \text { whites } \\
(P=0.01)\end{array}$ & $\begin{array}{l}\text { The worse survival among blacks } \\
\text { compared with whites after } \\
\text { allogeneic HSCT was in part } \\
\text { related to recurrent malignancy } \\
\text { and more severe GVHD, which } \\
\text { itself is at least partially attributable } \\
\text { to the difficulty of finding suitable } \\
\text { donors }\end{array}$ \\
\hline $\begin{array}{l}\text { Hari et al. } \\
(2010)\end{array}$ & $\begin{array}{l}\text { CIBMTR from } \\
\text { 1995-2005 }\end{array}$ & $\begin{array}{l}\text { Patients }(n=2,195) \\
\text { adult recipients of } \\
\text { autologous HSCT } \\
\text { for MM }\end{array}$ & $\begin{array}{l}\text { Overall survival: Black } 0.94(0.78-1.13)(P=0.50) \\
\text { Progression-free survival: Black } 0.94(0.81-1.09) \\
(P=0.39)\end{array}$ & $\begin{array}{l}\text { Black recipients of autologous } \\
\text { HSCT for MM have similar } \\
\text { outcomes compared to whites, } \\
\text { suggesting that the reasons } \\
\text { underlying lower rates of } \\
\text { autologous HSCT in blacks needs } \\
\text { further study to ensure equal } \\
\text { access to effective therapy }\end{array}$ \\
\hline
\end{tabular}

Table 2 (continued) 
Table 2 (continued)

\begin{tabular}{|c|c|c|c|c|}
\hline Reference & Data source & $\begin{array}{l}\text { Population } \\
\text { characteristics }\end{array}$ & Results $^{*}$ (as compared to white patients) ${ }^{1}$ & Conclusion \\
\hline $\begin{array}{l}\text { Ballen } \\
\text { et al. } \\
(2012)\end{array}$ & $\begin{array}{l}\text { CIBMTR from } \\
\text { 1995-2006 }\end{array}$ & $\begin{array}{l}\text { Patients }(\mathrm{n}=885) \\
\text { adults and } \\
\text { children who } \\
\text { received unrelated } \\
\text { single UCBT for } \\
\text { leukemia and } \\
\text { myelodysplastic } \\
\text { syndrome }\end{array}$ & $\begin{array}{l}\text { Overall survival: Black } 1.31(1.04-1.66)(P=0.02) \\
\text { Hispanic } 1.03(0.79-1.35)(P=0.80)\end{array}$ & $\begin{array}{l}\text {-Black patients had inferior overall } \\
\text { survival while overall survival of } \\
\text { Hispanic patients was similar to } \\
\text { white patients after single UCBT, } \\
\text { but outcomes are improved when } \\
\text { units with higher cell dose are } \\
\text { used }\end{array}$ \\
\hline $\begin{array}{l}\text { Eckrich } \\
\text { et al. } \\
(2014)\end{array}$ & $\begin{array}{l}\text { CIBMTR data from } \\
\text { 1990-2008 }\end{array}$ & $\begin{array}{l}\text { Patients ( } \mathrm{n}=299 \text { ) } \\
\text { with severe } \\
\text { aplastic anemia } \\
\text { who underwent } \\
\text { HSCT }\end{array}$ & $\begin{array}{l}\text { Overall mortality: AA } 1.73(1.11-2.68)(P<0.01) \\
\text { early post-transplant period: AA } 2.33(1.15-4.75) \\
(P=0.02) \text {; late post-transplant period: } A A 2.62 \\
(1.33-5.15)(P<0.01)\end{array}$ & $\begin{array}{l}\text {-There are lower survival rates in } \\
\text { African Americans with severe aplastic } \\
\text { anemia compared to white patients } \\
\text { after allogeneic transplantation when } \\
\text { adjusting for age, performance score, } \\
\text { interval from diagnosis to transplant, } \\
\text { donor source, graft source, and } \\
\text { transplant period }\end{array}$ \\
\hline $\begin{array}{l}\text { Pulte et al. } \\
\text { (2014) }\end{array}$ & $\begin{array}{l}\text { SEER database } \\
\text { from 1998-2001 } \\
\text { and } 2006-2009\end{array}$ & $\begin{array}{l}\text { Patients with } \\
\text { multiple myeloma }\end{array}$ & $\begin{array}{l}\text { Overall mortality (2006-2009): AA } 1.20 \text { (1.09- } \\
\text { 1.33); Hispanic } 1.25 \text { (1.11-1.41) }\end{array}$ & $\begin{array}{l}\text { Persistent excess mortality was } \\
\text { seen for African American and } \\
\text { Hispanic patients with MM. These } \\
\text { inequalities persisted or even } \\
\text { increased from 1998-2001 to } \\
2006-2009 \text { which suggests that } \\
\text { ethnic minorities may not have } \\
\text { benefitted from new treatments to } \\
\text { the same extent as white patients }\end{array}$ \\
\hline $\begin{array}{l}\text { Patel et al. } \\
\text { (2014) }\end{array}$ & $\begin{array}{l}\text { Stanford } \\
\text { University } \\
\text { database from } \\
\text { 1998-2012 }\end{array}$ & $\begin{array}{l}\text { Patients }(\mathrm{n}=3,407) \\
\text { who received } \\
\text { autologous or } \\
\text { allogeneic HSCT }\end{array}$ & $\begin{array}{l}\text { Overall mortality: autologous HSCT: Asian/PI } \\
1.25 \text { (1.01-1.57) }(\mathrm{P}<0.05) \text {, Black } 0.97(0.69-1.35) \text {, } \\
\text { Hispanic } 0.82(0.61-1.10) \text {; allogeneic HSCT: no } \\
\text { mortality disparities }\end{array}$ & $\begin{array}{l}\text { After adjustment for individual, } \\
\text { clinical, socioeconomic, and } \\
\text { insurance status factors, there is } \\
\text { increased mortality after autologous } \\
\text { transplant and higher likelihood of } \\
\text { treatment-related morbidity after } \\
\text { allogeneic transplant among Asian/ } \\
\text { Pacific Islander patients }\end{array}$ \\
\hline $\begin{array}{l}\text { Bhatnagar } \\
\text { et al. } \\
(2015)\end{array}$ & $\begin{array}{l}\text { University of } \\
\text { Maryland Hospital } \\
\text { Center between } \\
2000-2013\end{array}$ & $\begin{array}{l}\text { Patients }(n=625) \\
\text { with MM who } \\
\text { underwent } \\
\text { autologous HSCT }\end{array}$ & $\begin{array}{l}\text { Overall survival from transplant: White } 5.7 \text { years, } \\
\text { Black } 6.2 \text { years }(P>0.05) \\
\text { Overall survival from diagnosis: White } 7.7 \text { years, } \\
\text { Black } 6.1 \text { years }(P=0.03)\end{array}$ & $\begin{array}{l}\text { There are ethnic differences in } \\
\text { age, referral patterns, response to } \\
\text { therapy, and overall survival }\end{array}$ \\
\hline $\begin{array}{l}\text { Khera } \\
\text { et al. } \\
(2015)\end{array}$ & $\begin{array}{l}\text { Single Center } \\
\text { Study between } \\
\text { 2003-2012 }\end{array}$ & $\begin{array}{l}\text { Patients }(n=296) \\
\text { who underwent } \\
\text { allogeneic HSCT }\end{array}$ & $\begin{array}{l}\text { Both unadjusted and adjusted overall and } \\
\text { progression-free survival were comparable } \\
\text { between groups }\end{array}$ & $\begin{array}{l}\text { Homogeneity of medical care } \\
\text { for allogeneic HSCT may help } \\
\text { overcome racial/ethnic disparities }\end{array}$ \\
\hline $\begin{array}{l}\text { Costa } \\
\text { et al. } \\
(2017)\end{array}$ & $\begin{array}{l}\text { SEER Database } \\
\text { between 1993- } \\
2012\end{array}$ & $\begin{array}{l}\text { Patients } \\
(n=34,505) \text { with } \\
M M\end{array}$ & $\begin{array}{l}\text { Trends in } 10 \text {-year survival }(1993-1997,2003- \\
\text { 2007): White, } 13.2 \% \text { to } 24.3 \%(P<0.01) \text {; Black, } \\
\text { 14.6\% to } 23.4 \%(P<0.01) \text {; Hispanic, } 13.0 \% \text { to } \\
\text { 23.8\% }(P<0.01)\end{array}$ & $\begin{array}{l}\text { Much of the improvement in MM } \\
\text { survival is credited to broader } \\
\text { use of autologous HSCT, but this } \\
\text { modality continues to be poorly } \\
\text { utilized among patients older than } \\
65 \text { years of age; patients of ethnic } \\
\text { minorities are nearly } 50 \% \text { less } \\
\text { likely to access autologous HSCT } \\
\text { compared to white patients }\end{array}$ \\
\hline
\end{tabular}

Table 2 (continued) 
Table 2 (continued)

\begin{tabular}{|c|c|c|c|c|}
\hline Reference & Data source & $\begin{array}{l}\text { Population } \\
\text { characteristics }\end{array}$ & Results $^{\star}$ (as compared to white patients) ${ }^{1}$ & Conclusion \\
\hline $\begin{array}{l}\text { Bona et al. } \\
\text { (2021) }\end{array}$ & $\begin{array}{l}\text { CIBMTR between } \\
\text { 2006-2015 }\end{array}$ & $\begin{array}{l}\text { Patients }(n=2,053) \\
\text { with malignant } \\
\text { disease and } \\
\text { patients }(n=1,696) \\
\text { with non-malignant } \\
\text { disease who were } \\
\text { less than } 18 \text { years } \\
\text { old at the time of } \\
\text { allogeneic HSCT }\end{array}$ & $\begin{array}{l}\text { Malignant disease: overall mortality at } 100- \\
\text { days, Black } 1.47(1.20-1.81)(\mathrm{P}<0.01) \text {; TRM, } \\
\text { Black } 1.65(1.26-2.17)(\mathrm{P}<0.01) \text {; there were no } \\
\text { differences in relapse, acute or chronic GVHD, or } \\
\text { infection through day } 100 \\
\text { Non-malignant disease: neither race nor ethnicity } \\
\text { was associated with HSCT among children with } \\
\text { non-malignant disease }\end{array}$ & $\begin{array}{l}\text { There was an independent } \\
\text { association between black race } \\
\text { and inferior overall survival and } \\
\text { TRM among children undergoing } \\
\text { transplantation for malignant disease, } \\
\text { specifically, children of black race } \\
\text { experienced a } 47 \% \text { increased risk } \\
\text { of death and } 65 \% \text { increased risk of } \\
\text { TRM compared with white race }\end{array}$ \\
\hline
\end{tabular}

\begin{abstract}
*, unless otherwise stated, $\mathrm{P}<0.05 .{ }^{1}$, unless otherwise stated, reference group is white patients; ${ }^{\text {, }}$ Reference Group: Patients in centers performing $<20 \%$ of minority transplants; ' , Reference Group: Patients in centers performing $<10 \%$ of Hispanic patient transplants. $A A$, African Americans; BMT, bone marrow transplant; HMO, healthcare maintenance organization; HSCT, hematopoietic stem cell transplant; $A L L$, acute lymphocytic leukemia; $C L L$, chronic lymphocytic leukemia; $A M L$, acute myelogenous leukemia; $C M L$, chronic myelogenous leukemia; NHL, non-Hodgkin lymphoma; GVHD, graft versus host disease; TRM, treatment related mortality; SEER, Surveillance Epidemiology and End Results; CIBMTR, Center for International Blood and Marrow Transplant Research; NMDP, National Marrow Donor Program; URD, unrelated donor; $S C D$, sickle cell disease.
\end{abstract}

were $[2.05(1.47-2.85)]$ as likely as white patients to have only partial HLA-matching (4), and those with multiple myeloma had a lower relative utilization [RUR $0.65(0.58-$ $0.73), \mathrm{P}<0.01]$ of HSCT when compared to the entire group of myeloma patients (6).

Two longitudinal studies which evaluated either the likelihood of potential stem cell donors to opt out of donation or the correlation of self-identification of race/ ethnicity with HLA-subtype showed that potential Asian donors 18-60 years of age had a high association of ambivalence about donation $(22.16, \mathrm{P}<0.01)(9)$, but that those with mental health issues (e.g., anxiety, depression) had a decreased likelihood of opting out of donation (0.90, $\mathrm{P}<0.01)$. Potential Asian stem cell donors had the highest correlation $(\mathrm{R}=0.84)$ with self-identification of race/ ethnicity and HLA-matching (10).

\section{Black disparities in access to HSCT}

Racial disparities in HSCT amongst black patients were by far the most frequently studied group. Fourteen of the seventeen included publications evaluated black race as a function of HSCT utilization, with nine of these being retrospective analyses. Initial studies of racial disparities were performed by Mitchell et al. (11) in the late 1990s, which evaluated in-patient discharge data from four separate states and compared racial proportions of leukemia and lymphoma patients who were referred for HSCT. African Americans with leukemia were $51-53 \%$ as likely to undergo HSCT, while those with lymphoma were $34-45 \%$ as likely as their white counterparts to undergo HSCT $(\mathrm{P}<0.05)$. The likelihood of black patients finding only a partial HLA-match was $2.83(2.26-3.54)$ in the study by Dehn et al. (4), the highest likelihood of any race/ethnicity. Joshua et al. (12) studied patients less than 70 years old with acute or chronic leukemia, multiple myeloma or nonHodgkin lymphoma. When compared to black patients, white patients were more likely to undergo any kind of HSCT [1.40 (1.34-1.46)]. When stratified by type of transplant, white patients consistently were more likely to receive autologous transplant [1.24 (1.19-1.30)], HLAsibling matched transplant [1.59 (1.46-1.74)], or unrelated donor transplant [2.02 (1.75-2.33)].

Clay et al. (13) studied 18- to 75 -year-old patients with a new diagnosis of acute or chronic leukemia, Hodgkin or non-Hodgkin lymphoma, or multiple myeloma who were referred for HSCT. The proportion of African American patients (57\%) who were referred for HSCT was significantly lower than white patients $(62 \%)$. Upon further evaluation, the most common reasons that African Americans in this group did not receive HSCT were physician decision (29\%), death before transplant (16\%), or transfer to another center (13\%). White patients in this study were more often not referred for transplant because of treatment reluctance $(20 \%)$, stable disease $(20 \%)$, death before transplant (19\%) or disease progression (14\%). Patients with multiple myeloma who underwent autologous HSCT were evaluated by Bhatnagar et al. (14) 


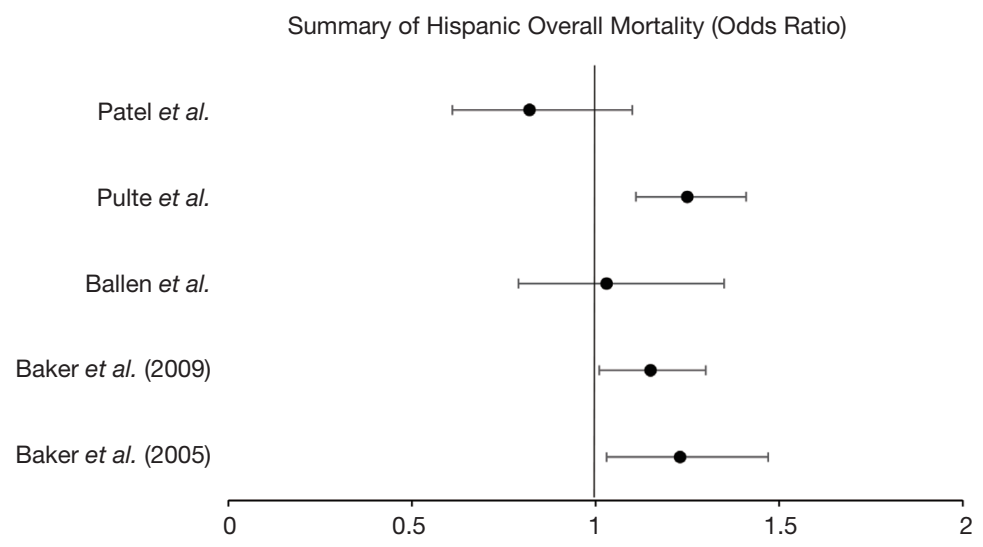

Figure 2 Summary of publications evaluating overall mortality in Hispanic patients.

to determine discrepancies in time to referral by providers. African American patients had significantly increased time to referral (1.3 years, SD 1.5 years) vs. white patients (0.9 years, SD 1.0 years, $\mathrm{P}<0.01$ ). The relative utilization rate of HSCT by African Americans created by Costa et al. (6) showed that blacks $[0.69(0.67-0.72), \mathrm{P}<0.01]$ had a significantly decreased utilization when compared to the entire group. Besse et al. (5) found that the likelihood of black patients finding an identical HLA-matched sibling donor within the 20-25-year age group was similar to white patients (30\% vs. $25-30 \%)$, but significantly different as age groups increased to 40 to 45 years old (53\% blacks vs. $42 \%$ whites) and those older than 55 years of age (48\% blacks vs. $16 \%$ whites). Black patients with acute lymphocytic or myelogenous leukemia in California (7) were less likely to undergo HSCT [0.40 (0.18-0.89)] and [0.60 (0.44-0.83)], respectively. Finally, in black patients with $\mathrm{AL}$ amyloidosis (8) who underwent HSCT there was a non-significantly decreased utilization $[0.81(0.43-1.50)]$ when compared to white patients.

Three longitudinal studies evaluated either the likelihood of black patients being referred for HSCT, the likelihood of black potential stem cell donors to opt out of donation, or the correlation of self-identification of black potential donors to their actual HLA-type. Pidala et al. (15) evaluated oncologists to determine the likelihood of referral by race. This study found that black patients were significantly more likely to not be referred for HSCT when compared to white patients [2.35 (1.93-2.87), $\mathrm{P}<0.01]$. The crosssectional study by Switzer et al. (9) found that potential donors of black race were ambivalent $(14.09, \mathrm{P}<0.01)$ about donation. Additionally, having higher education, defined as at least a bachelor's degree, was also significantly associated with opting out of donation $(2.61, \mathrm{P}<0.01)$ in those of black race. Finally, black patients had a high correlation of selfidentification with HLA-matching $(\mathrm{R}=0.71)$ when evaluated by Hollenbach et al. (10).

Two publications designed to determine barriers of HSCT utilization and knowledge through focus groups were included in this analysis. Young African American patients with sickle cell disease and their parents were asked about racial bias and health-related stigma. The main barriers to HSCT access in these groups were determined to be limited access to information about transplant procedure and mistrust of medical professionals (16). Most patients surveyed endorsed occurrences of racial bias and health-related stigma (17).

We included fourteen publications which evaluated racial disparities in survival after HSCT (Table 2). The publications were all retrospective cohort studies, either from a single center or a national database. Thirteen of the fourteen $(93 \%)$ publications found racial disparities in either overall survival, progression free survival, treatment related mortality, relapse, or combinations of these outcomes (Figures 2-4).

\section{Hispanic disparities in survival}

Eight of the publications assessed for racial disparities in the Hispanic population. In one study evaluating HLA-identical siblings (18) in acute or chronic leukemia, Hispanics' 1-year and 3 -year survival were significantly decreased when compared to white patients (1-year: $53 \%$ vs. $65 \%, \mathrm{P}<0.01$; 3 -year: $38 \%$ vs. $53 \%, \mathrm{P}<0.01)$. A second study (19) in HLAidentical siblings found significantly increased treatment failure [RR 1.30 (1.08-1.54)] and overall mortality [RR 1.23 


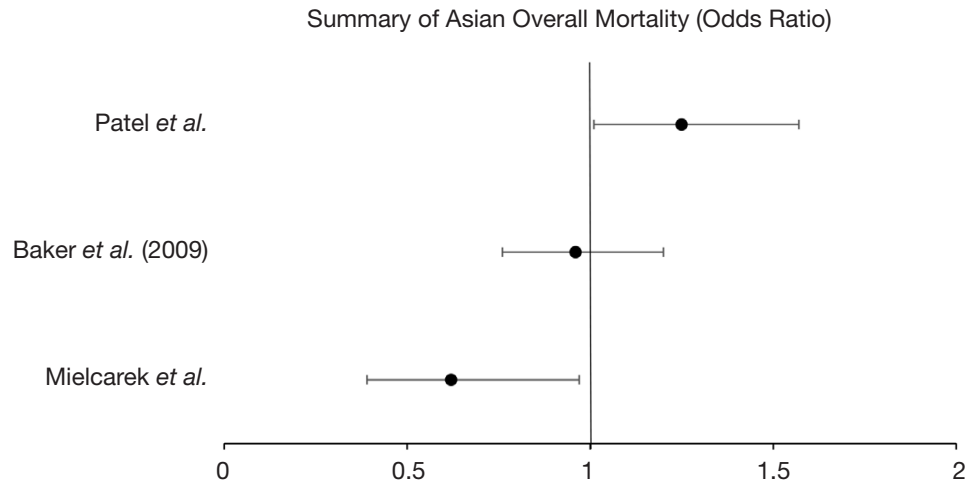

Figure 3 Summary of publications evaluating overall mortality in Asian patients.

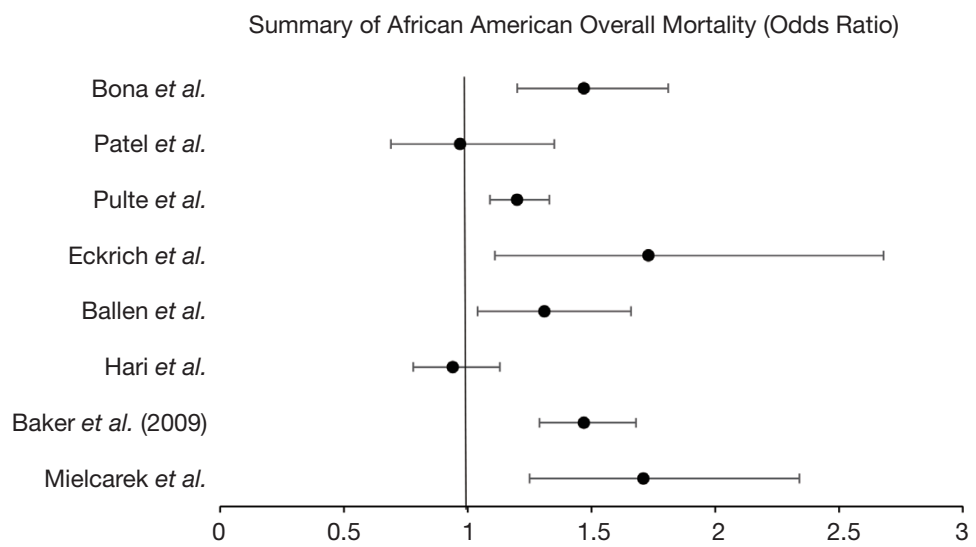

Figure 4 Summary of publications evaluating overall mortality in African American patients.

(1.03-1.47)] when compared to white patients undergoing HSCT for acute or chronic leukemia. Schwake et al. (20) evaluated transplant centers which performed HSCT in a larger proportion $(>20 \%)$ of minority patients, specifically with $>10 \%$ of Hispanic patients. This study found similar mortality in 100-day survival in Hispanic patients at these centers [HR $0.99(0.72-1.36)]$ but did find that the centers which perform transplant in a higher proportion of ethnic minorities perform fewer total transplants per year.

Baker et al. (21) evaluated patients undergoing unrelated donor HSCT for acute or chronic leukemia and found slightly increased mortality in Hispanics compared to white patients [1.15 (1.01-1.30)] with decreased disease-free survival [1.14 (1.00-1.29)] and increased treatment-related mortality [1.30 (1.11-1.51)], despite a non-significant, yet mild decrease in disease relapse [0.87 (0.70-1.09)]. A fifth study by Ballen et al. (22) found no significant increase in overall mortality for Hispanics [1.03 (0.79-1.35), $\mathrm{P}=0.80$ ] compared to whites when evaluating adults and children who underwent unrelated, single umbilical cord blood transplant (UCBT) for leukemia or myelodysplastic syndrome. Hispanic patients with multiple myeloma studied by Pulte et al. (23) had increased mortality [1.25 (1.11-1.41)] compared to white patients with multiple myeloma. A study at Stanford university (24) found a non-significant decrease in overall mortality in Hispanic patients undergoing autologous HSCT [0.82 (0.61-1.10)] and no disparities in mortality in allogeneic HSCT when compared to white patients. Finally, trends in 10-year survival in multiple myeloma were studied by Costa et al. (25), which found that Hispanic patients have significant increase in their 10-year survival $(13 \%$ to $23.8 \%, \mathrm{P}<0.01)$ when evaluated between 1993-1997 and 2003-2007.

\section{Asian disparities in survival}

Three of the retrospective studies evaluated survival differences in Asian patients. Mielcarek et al. (26) found no 
significant associations in autologous HSCT but did find a slightly improved survival in Asian patients who underwent allogeneic transplant [0.62 (0.39-0.97), $\mathrm{P}<0.05]$. Patients with acute or chronic leukemia who received an HLAidentical sibling matched HSCT evaluated by Baker et al. (21) found a non-significant improvement in overall survival [0.96 (0.76-1.20)] with non-significant increases in disease relapse $[1.13(0.80-1.61)]$ and treatment related mortality [0.99 (0.75-1.32)]. In a study from Stanford University (24), Asian and Pacific Islander patients who received autologous HSCT had significantly increased mortality [1.25 (1.011.57)], but no disparities noted in Asian patient undergoing allogeneic transplantation.

\section{Black disparities in survival}

Survival outcomes were overwhelmingly studied in the black population with ten retrospective analyses included in our review. While no significant associations between race and autologous HSCT were found in black patients studied by Mielcarek et al. (26), there was significantly increased mortality in those undergoing allogenic transplant [1.71 $(1.25-2.34)]$ with a non-significant, yet higher likelihood of recurrent malignancy [1.61 (0.95-2.73)]. There was a quite significant difference in severe graft vs host disease (61\% in blacks, $36 \%$ whites, $\mathrm{P}=0.01$ ) noted between the groups. Overall mortality [1.47 (1.29-1.68), $\mathrm{P}<0.01)$, relapse of malignancy [1.56 (1.34-1.83), $\mathrm{P}<0.01)$, and treatment-related mortality [1.56 (1.34-1.83), $\mathrm{P}<0.01]$ were all significantly increased in black patients undergoing unrelated donor HSCT for acute or chronic leukemia or myelodysplastic syndrome in a study by Baker et al. (21). While black patients with leukemia and myelodysplastic syndrome who received unrelated single umbilical cord blood transplant also had significantly worse overall survival [1.31 (1.04-1.66), $\mathrm{P}=0.02$ ] (22). 100-day mortality [1.47 (1.20-1.81), $\mathrm{P}<0.01]$ and treatment-related mortality [1.65 (1.26-2.17), $\mathrm{P}<0.01]$ were significantly worse in black patients with malignant disease who underwent allogeneic HSCT (27). Notably, those who underwent this transplantation for non-malignant disease showed no association between survival and race.

Black patients with severe aplastic anemia who underwent HSCT were studied by Eckrich et al. (28) and found to have significantly worse overall survival $[1.73$ (1.11-2.68), $\mathrm{P}<0.01)$, which was further stratified by early [2.33 (1.15-4.75), $\mathrm{P}=0.02]$ and post-transplant [2.62 (1.33-5.15), $\mathrm{P}<0.01]$ period mortality. While black patients who received autologous HSCT at a Stanford University study (23) had non-significant, yet slightly decreased overall mortality [0.97 (0.69-1.35)].

Hari et al. (29) studied adult recipients of autologous HSCT in patients with multiple myeloma and found nonsignificant, yet slightly decreased overall mortality [0.94 $(0.78-1.13), \mathrm{P}=0.50]$ and poorer progression free survival [0.94 (0.81-1.09), $\mathrm{P}=0.39$ ]. Pulte et al. (23) found black patients with multiple myeloma evaluated during 2006-2009 had significantly increased overall mortality [1.20 (1.091.33)], while Bhatnagar et al. (14) studied how overall survival differs from time of transplant versus time of diagnosis in multiple myeloma patients and found that black patients had similar, non-significant survival time from transplant $(6.2$ vs. 5.7 years in whites, $\mathrm{P}>0.05$ ), but did have significantly decreased survival from time of diagnosis $(6.1 \mathrm{vs} .7 .7$ years in whites, $\mathrm{P}=0.03)$. These mortality trends in 10 -year survival were analyzed by Costa et al. (25), who found that black patients had significant increases in overall survival between 1993-1997 vs. 2003-2007 (14.6\% to $23.4 \%, \mathrm{P}<0.01)$.

\section{Discussion}

\section{Background}

The process by which potential donors and patients are matched depends largely on the concordance of HLA on the cell surface. These are the proteins which are expressed by all cells and recognized by $\mathrm{CD} 8^{+} \mathrm{T}$ cells, chiefly HLA-A, B, and C. In autologous and syngeneic transplantation, the HLA types are identical, therefore, the risk of graft vs host disease (GVHD) and graft failure are very low (30). In allogeneic transplantation, the donor is an HLA-matched family member, an unrelated donor, or mismatched family member. The mismatch in HLA proteins leads to inappropriate recognition by the host's immune system with subsequent graft failure. The risk of transplant-related mortality (TRM), disease relapse, and chronic GVHD in allogeneic bone marrow transplant from HLA-identical siblings led to the discovery of umbilical cord blood transplantation in 1988 (31). The advantages of cord blood transplant include less infection risk, lower rates of GVHD, and less need for stringent HLA matching; however, a single unit of cord blood often is inadequate for transplantation $(30,31)$.

The original indications for HSCT were for leukemia and lymphoma, however, the indications for transplant are rapidly expanding. HSCT is now considered either first 
line treatment or refractory treatment for many malignant hematologic diseases including multiple myeloma, Hodgkin or non-Hodgkin lymphoma, acute or chronic leukemia, myelodysplastic syndrome, myelofibrosis, essential thrombocytosis, and polycythemia vera. Solid tumors such as germ cell tumors refractory to chemotherapy, medulloblastoma, and metastatic breast cancer have also been studied with improvement in overall survival (32). Non-malignant hematologic conditions such as aplastic anemia, severe combined immunodeficiency syndrome, thalassemia, and sickle cell disease continue to show benefit with HSCT.

\section{Access to bematopoietic stem cell transplant}

Initial retrospective studies examining differences between patients who utilize HSCT were conducted in the late 1990s by Mitchell et al. (11). These early findings began to elucidate a racial disparity in leukemia and lymphoma treatment with slightly less utilization of HSCT by blacks when compared to white patients. Subsequent studies over the next several decades continued to suggest that white patients receive higher referral rates for HSCT, better rates of HLA-matching, and differences in progression free and overall survival. Early studies hypothesized that having less insurance coverage reduces the likelihood that patients will be referred for HSCT (33). Additionally, many ethnic minorities are unable to obtain full matches in HLA due to lack of potential donors. The likelihood of ethnic minorities to undergo HSCT with only partial HLA-matching is significantly elevated. Studies in minority sickle cell patients (34) being evaluated for transplant have shown that perceived racial bias and health related stigma are important areas to address as psychological stigma plays a significant role in access. If a patient's disease course prompts a referral for HSCT, early discovery of potential donors is paramount to improve outcomes in survival and reduce disparities.

Multiple myeloma (MM) represents $1.8 \%$ of all new cancer cases in the United States each year but carries a $55 \%$-year survival (35). Multiple myeloma is the most common hematologic cancer affecting African American persons, with estimates of two-to-three times increased frequency when compared to white patients (36). While a biological variation cannot be excluded, our review indicates that black patients are significantly less likely to be referred for HSCT. The most likely reasons for this seem to be a mixture of biological and provider based. One third of black patients are not referred to HSCT due to physician decision, whereas forty percent of white patients are not referred for either treatment reluctance or stable disease. While provider reasoning for non-referral is likely clinically based, the lower likelihood of complete HLA-matching coupled with the poorer diversity in the potential stem cell donor pool stress the need for provider-patient education and shared decision making.

Asian and Hispanic patients also showed some differences in utilization when compared to white patients. Both groups had increased likelihood of only partial-HLA matching and decreased relative utilization rates, but Hispanic potential stem cell donors were overwhelming less likely to donate and more likely to report being discouraged to donate.

In 2014, the Affordable Care Act (ACA) became fully implemented. For patients who were potential candidates for HSCT, this meant increased access to specialized providers and high-cost treatment options for critically ill patients. A main goal of the ACA expansion was to expand coverage and improve affordability by opening health care insurance exchanges which would allow for increased number and types of policies. The current reimbursement of services for HSCT is often a "bundled payment" model, with facilities and providers being paid a set amount for a diagnosis group (37). This expansion of coverage for uninsured or underinsured has led to approximately $40 \%$ of HSCT procedures performed in the United States now reimbursed by governmental payers (38). Eight of the included studies evaluating access to HSCT were performed after 2014. Three of these studies specifically evaluated utilization and found that ethnic minorities with multiple myeloma, ALL, AML, and AL amyloidosis are still underutilizing HSCT, with significant differences in referral and time to referral for African Americans.

\section{Survival in hematopoietic stem cell transplant}

Social determinants of health are known to be significantly associated with access and quality of healthcare $(39,40)$. Analyses of National Cancer Institute's SEER Program have shown that late-stage diagnoses are often associated with lower socioeconomic status, illustrating the potential for disparities in outcomes. Some of the earliest studies of survival by Serna et al. in 2003 suggested that despite adjustment for clinical factors, disparities exist in survival rates between Hispanics and whites. Our review found five studies which predicted overall mortality in Hispanics, with four of five studies showing a positive association. One study (40) found similar overall progression free survival 
between groups, hypothesizing that racial/ethnic disparities may be overcome by homogeneity of medical care. Higher risks of treatment related failure and mortality in Hispanics may be the net result of modest, yet not statistically significant increases in relapse and treatment-related mortality. While timely access to HSCT may improve overall survival, centers which performed transplantation in higher proportions of minorities (specifically Hispanics) had comparable 100-day survival rates between Hispanics and white patients, indicating that even when access is equalized there is continued mortality risk in Hispanics. Further research into genetic components which predispose Hispanic patients to treatment failure should be pursued as a possible explanation.

While Asian patients were noted to have a higher likelihood of partial HLA-matching despite a lower utilization rate of HSCT, Asian patients showed significant variation in survival in our review. In the three publications included, Asian patients had improved survival in two studies and increased mortality in a single center study. The Stanford study concluded that after adjustment for individual, clinical, sociodemographic and insurance status factors, there was increased mortality after autologous HSCT and a higher likelihood of treatment-related morbidity among Asian and Pacific Islander patients.

The most profound findings from our review are those noted in African American patients. Eight of the publications evaluated mortality differences in black patients and six of the eight showed a significantly increased association. Overall, worse survival was noted in black patients in all types of transplants. This increase in mortality is likely multifactorial with associated increased rates of relapse, treatment-related mortality, and severe graft $v s$. host disease.

Inequalities in excess mortality in patients with multiple myeloma were seen in African American patients. Overall mortality trends significantly increased between the periods of 1998-2001 to 2006-2009. These findings suggest that ethnic minorities may not be benefitting from improvements in treatments in multiple myeloma in the same extent as white patients. Recent studies by Fillmore et al. (37) identified over 15,000 patients with symptomatic multiple myeloma in the VA health center between 2000-2017 and found superior overall survival in African Americans, particularly in the younger population. While these findings suggest that with standardized, equal access treatment African Americans can achieve similar or improved survival, it should be noted that only $9 \%$ of this population received a transplant, indicating that survival advantages were achieved with chemotherapy or biologic treatment.

\section{Study limitations}

Our review is subject to several limitations. Because our aim was to determine whether the expansion of the Affordable Care Act has led to increased utilization of HSCT by minorities and indirectly increased mortality, more studies conducted on racial disparities need to be performed and included to determine a true effect. Additionally, many of the articles included have focused mainly on utilization and survival in African American patients. In order to fully understand the scope of the issue, more studies need to be conducted in Asian and Hispanic populations. Cultural issues surrounding access and utilization of healthcare in minority communities may also lead to biased views or perspectives. The inclusion of focus groups in minority communities which give examples of cultural and individual perspectives may aid in further understanding of these problems. The review process was also limited by those studies included in publicly accessible databases.

\section{Conclusions}

Race is a known predictor of health-related outcomes and racial disparities have been shown to be prevalent in a multitude of diseases, including cancer. Hematopoietic stem cell transplant is a complex and expensive procedure which requires multiple specialists, frequent monitoring, and high doses of chemotherapy and/or radiation. Increases in healthcare access from the institution of the Affordable Care Act has the capability of increasing access to these therapies and providers. Because a majority of transplants are allogeneic and require optimized HLA-matching, disparities in stem cell transplant may include donor, patient, and provider characteristics. While variation in overall mortality between ethnic minorities and white patients has traditionally been attributed to decreased utilization of stem cell transplant, our review revealed that discouragement of potential donors, differences in treatment failure and/or transplant rejection, and overall stigmatization and mistrust of the medical profession likely play significant roles in continued, worse outcomes seen in minority patients. Increased health literacy, access to transplant information and referral patterns, and continued improvement in patient-provider relationships are manageable and pertinent solutions which can ultimately improve patient outcomes. 


\section{Acknowledgments}

Vikram Sumbly, MD (independent reviewer).

Funding: None.

\section{Footnote}

Reporting Checklist: The author has completed the PRISMA reporting checklist. Available at https://dx.doi. org/10.21037/sci-2021-058

Conflicts of Interest: The author has completed the ICMJE uniform disclosure form (available at https://dx.doi. org/10.21037/sci-2021-058). The author has no conflicts of interest to declare.

Ethical Statement: The author is accountable for all aspects of the work in ensuring that questions related to the accuracy or integrity of any part of the work are appropriately investigated and resolved.

Open Access Statement: This is an Open Access article distributed in accordance with the Creative Commons Attribution-NonCommercial-NoDerivs 4.0 International License (CC BY-NC-ND 4.0), which permits the noncommercial replication and distribution of the article with the strict proviso that no changes or edits are made and the original work is properly cited (including links to both the formal publication through the relevant DOI and the license). See: https://creativecommons.org/licenses/by-nc-nd/4.0/.

\section{References}

1. Phelan R, Arora M, Chen M. Current use and outcome of hematopoietic stem cell transplantation: CIBMTR US summary slides, 2020.

2. National Institutes of Health Study Quality Assessment Tool for Systematic Re-views. Available online: https://www. nhlbi.nih.gov/health-topics/study-quality-assessment-tools

3. Hwang JP, Lam TP, Cohen DS, et al. Hematopoietic stem cell transplantation among patients with leukemia of all ages in Texas. Cancer 2004;101:2230-8.

4. Dehn J, Arora M, Spellman S, et al. Unrelated donor hematopoietic cell transplantation: factors associated with a better HLA match. Biol Blood Marrow Transplant 2008;14:1334-40.

5. Besse K, Maiers M, Confer D, et al. On Modeling Human Leukocyte Antigen-Identical Sibling Match Probability for Allogeneic Hematopoietic Cell Transplantation: Estimating the Need for an Unrelated Donor Source. Biol Blood Marrow Transplant 2016;22:410-7.

6. Costa LJ, Huang JX, Hari PN. Disparities in utilization of autologous hematopoietic cell transplantation for treatment of multiple myeloma. Biol Blood Marrow Transplant 2015;21:701-6.

7. Jabo B, Morgan JW, Martinez ME, et al. Sociodemographic disparities in chemotherapy and hematopoietic cell transplantation utilization among adult acute lymphoblastic and acute myeloid leukemia patients. PLoS One 2017;12:e0174760.

8. Staron A, Connors LH, Zheng L, et al. Race/ethnicity in systemic AL amyloidosis: perspectives on disease and outcome disparities. Blood Cancer J 2020;10:118.

9. Switzer GE, Bruce JG, Myaskovsky L, et al. Race and ethnicity in decisions about unrelated hematopoietic stem cell donation. Blood 2013;121:1469-76.

10. Hollenbach JA, Saperstein A, Albrecht M, et al. Race, Ethnicity and Ancestry in Unrelated Transplant Matching for the National Marrow Donor Program: A Comparison of Multiple Forms of Self-Identification with Genetics. PLoS One 2015;10:e0135960.

11. Mitchell JM, Meehan KR, Kong J, et al. Access to bone marrow transplantation for leukemia and lymphoma: the role of sociodemographic factors. J Clin Oncol 1997;15:2644-51.

12. Joshua TV, Rizzo JD, Zhang MJ, et al. Access to hematopoietic stem cell transplantation: effect of race and sex. Cancer 2010;116:3469-76.

13. Clay A, Peoples B, Zhang Y, et al. Population-Based Analysis of Hematologic Malignancy Referrals to a Comprehensive Cancer Center, Referrals for Blood and Marrow Transplantation, and Participation in Clinical Trial, Survey, and Biospecimen Research by Race. Biol Blood Marrow Transplant 2015;21:1488-94.

14. Bhatnagar V, Wu Y, Goloubeva OG, et al. Disparities in black and white patients with multiple myeloma referred for autologous hematopoietic transplantation: a single center study. Cancer 2015;121:1064-70.

15. Pidala J, Craig BM, Lee SJ, et al. Practice variation in physician referral for allogeneic hematopoietic cell transplantation. Bone Marrow Transplant 2013;48:63-7.

16. Omondi NA, Ferguson SE, Majhail NS, et al. Barriers to hematopoietic cell transplantation clinical trial participation of african american and black youth with sickle cell disease and their parents. J Pediatr Hematol Oncol 2013;35:289-98.

17. Majhail NS, Omondi NA, Denzen E, et al. Access to 
hematopoietic cell transplantation in the United States. Biol Blood Marrow Transplant 2010;16:1070-5.

18. Serna DS, Lee SJ, Zhang MJ, et al. Trends in survival rates after allogeneic hematopoietic stem-cell transplantation for acute and chronic leukemia by ethnicity in the United States and Canada. J Clin Oncol 2003;21:3754-60.

19. Baker KS, Loberiza FR Jr, Yu H, et al. Outcome of ethnic minorities with acute or chronic leukemia treated with hematopoietic stem-cell transplantation in the United States. J Clin Oncol 2005;23:7032-42.

20. Schwake CJ, Eapen M, Lee SJ, et al. Differences in characteristics of US hematopoietic stem cell transplantation centers by proportion of racial or ethnic minorities. Biol Blood Marrow Transplant 2005;11:988-98.

21. Baker KS, Davies SM, Majhail NS, et al. Race and socioeconomic status influence outcomes of unrelated donor hematopoietic cell transplantation. Biol Blood Marrow Transplant 2009;15:1543-54.

22. Ballen KK, Klein JP, Pedersen TL, et al. Relationship of race/ethnicity and survival after single umbilical cord blood transplantation for adults and children with leukemia and myelodysplastic syndromes. Biol Blood Marrow Transplant 2012;18:903-12.

23. Pulte D, Redaniel MT, Brenner H, et al. Recent improvement in survival of patients with multiple myeloma: variation by ethnicity. Leuk Lymphoma 2014;55:1083-9.

24. Patel MI, Schupp C, Gomez SL, et al. Are there disparities in transplant-related morbidity and mortality after hematopoietic stem cell transplant: an institution-based analysis of autologous and allogeneic transplant recipients. Blood 2014;124:1283.

25. Costa LJ, Brill IK, Omel J, et al. Recent trends in multiple myeloma incidence and survival by age, race, and ethnicity in the United States. Blood Adv 2017;1:282-7.

26. Mielcarek M, Gooley T, Martin PJ, et al. Effects of race on survival after stem cell transplantation. Biol Blood Marrow Transplant 2005;11:231-9.

27. Bona K, Brazauskas R, He N, et al. Neighborhood poverty and pediatric allogeneic hematopoietic cell transplantation outcomes: a CIBMTR analysis. Blood. 2021;137(4):556568. Blood 2021;138:2300.

28. Eckrich MJ, Ahn KW, Champlin RE, et al. Effect of race on outcomes after allogeneic hematopoietic cell transplantation for severe aplastic anemia. Am J Hematol 2014;89:125-9.

29. Hari PN, Majhail NS, Zhang MJ, et al. Race and outcomes of autologous hematopoietic cell transplantation for multiple myeloma. Biol Blood Marrow Transplant 2010;16:395-402.

30. Khaddour K, Hana CK, Mewawalla P. Hematopoietic
Stem Cell Transplantation. Treasure Island (FL): StatPearls Publishing; 2021.

31. U.S. Department of Health and Human Services Food and Drug Administration Center for Biologics Evaluation and Research. Guidance for Industry Minimally Manipulated, Unrelated, Allogeneic Placental/Umbilical Cord Blood Intended for Hematopoietic Reconstitution in Patients with Hematological Malignancies. DRAFT GUIDANCE. Office of Communication, Training and Manufacturers Assistance (HFM-40), 1401 Rockville Pike, Suite 200N, Rockville, MD, USA. December 2006.

32. Einhorn LH, Williams SD, Chamness A, et al. High-dose chemotherapy and stem-cell rescue for metastatic germcell tumors. N Engl J Med 2007;357:340-8.

33. Cho C. [Accessed 07-10-2021]. Factors affecting stem cell transplantation for leukemia and lymphoma. 2006. Available online: http://hdl.handle.net/1961/3595

34. Wakefield EO, Popp JM, Dale LP, et al. Perceived Racial Bias and Health-Related Stigma Among Youth with Sickle Cell Disease. J Dev Behav Pediatr 2017;38:129-34.

35. SEER Cancer Stat Facts: Myeloma. National Cancer Institute. Bethesda, MD, USA.

36. Baker A, Braggio E, Jacobus S, et al. Uncovering the biology of multiple myeloma among African Americans: a comprehensive genomics approach. Blood 2013;121:3147-52.

37. Fillmore NR, Yellapragada SV, Ifeorah C, et al. With equal access, African American patients have superior survival compared to white patients with multiple myeloma: a VA study. Blood 2019;133:2615-8.

38. Driscoll D, Farnia S, Kefalas P, et al. Concise Review: The High Cost of High Tech Medicine: Planning Ahead for Market Access. Stem Cells Transl Med 2017;6:1723-9.

39. Clegg LX, Reichman ME, Miller BA, et al. Impact of socioeconomic status on cancer incidence and stage at diagnosis: selected findings from the surveillance, epidemiology, and end results: National Longitudinal Mortality Study. Cancer Causes Control 2009;20:417-35.

40. Khera N, Chang YH, Slack J, et al. Impact of race and ethnicity on outcomes and health care utilization after allogeneic hematopoietic cell transplantation. Leuk Lymphoma 2015;56:987-92.

doi: 10.21037/sci-2021-058

Cite this article as: Landry I. Racial disparities in hematopoietic stem cell transplant: a systematic review of the literature. Stem Cell Investig 2021;8:24. 